\title{
硬さの異なる床面素材の識別容易性に関する研究 \\ How Accurately People Can Discriminate the Differences of Floor Materials with Various Elasticities
}

\author{
O小林吉之 1 ，大阪れい 2, 原利明 3，藤本浩志 2
}

\section{1. 国立身体障害者リハビリテーションセンター研究所, 2. 早稲田大学, 3. 鹿島建設}

OYoshiyuki Kobayashi ${ }^{1}$, Rei Osaka ${ }^{2}$, Toshiaki Hara ${ }^{3}$ and Hiroshi Fujimoto ${ }^{4}$

1. National Rehabilitation Center for Persons with Disabilities, 2. Waseda University, 3. KAJIMA Coporation

\section{1. 目的}

視覚障害者用誘導ブロック(以下, 誘導ブロック)は, 視覚障害 者の安全な歩行を誘導するために広く歩道などに敷設されてい る.この誘導ブロックに関しては現在 ISO でも検討が進められる などその有用性は世界的に評価されているが，同時に誘導ブロッ クを利用しない人にとってはその突起が余計なバリアとなりうる可 能性も指摘されている.

このような背景から, 近年屋内など安全性が高く確保されてい る空間においては，床面素材に突起以外の差を与えることで危 険箇所などの空間を提示しようとする試みが行われている. その もっとも基本的な差の与え方として, 硬さの異なる床材を用いる方 法があり, 複数の施設で既に実装されているが，具体的にどの程 度の差があればヒ卜は床材の硬さの違いを識別できているかにつ いては定量的・客観的に調べられた研究はない.そこで本研究で は, 様々な硬さの床材を提示し，歩行中にどの程度正確にそれら の違いを識別できるかを検証することで, 視覚障害者に空間を提 示するのに妥当な床材の硬さの差を明らかにすることを目的とす る.この研究は, 今後誰にとっても安全な歩行空間を検討する上 で非常に重要な資料となると考えている.

\section{2. 方法}

被験者は晴眼の大学生 10 名（男性 5 名, 女性 5 名）とし, 実験ではアイマスクで視覚を, 更にホワイトノイズを流した ヘッドホンを着用させることで足音の情報をそれぞれ遮蔽し た.これは，普段視賞を妨げられた状況で步行することに慣 れていない人々を対象とすることで，彼らが識別できる床材 の組み合わせであれば，普段から視覚情報を妨げられた状況 で歩行している視覚障害者によってはより正確に識別できる 組み合わせとなると考えたためである。

実験では， $728 \mathrm{~cm}$ の歩行路を前半部と後半部に分け，それ ぞれに表 1 に示した硬さの異なる素材 3 種類と，比較対照と しての通常の誘導ブロック 1 種類, 計 16 通りの歩行路を提示 した. 提示した床材の硬さについては，(社）日本道路協会が 定める弾力性試験方法 (GB 係数)を用いた.

被験者は提示された歩行路上をアイマスクとヘッドホンを 着用した状態で歩行し, 歩行し終えたところで前半部と後半 部の素材が異なっていたかを回答した。 その際被験者は，歩 行路上をまっすぐに歩けるように歩行路の脇に設置された手 すりに沿って歩行した. 床材は, 前半部と後半部が異なる試 行と同じ試行が $50 \%$ ずつ, 計 144 試行提示された。 また，床 材が切り替わる箇所が毎回同じとならないようにスタート地 点とゴール地点を 3 䉪所ずつ用意し，ランダムに提示するこ とで被験者の予見を防いだ。

\section{3. 結果}

先に提示した歩行路の素材を因子 $\mathrm{A}$, 後から提示した歩行路 の素材を因子 B とした二元配置分散分析の結果, 先に提示した 歩行路の主効果 $\left.\left(\mathrm{F}_{(3,27}\right)=18.385\right)$, 後から提示した歩行路の主

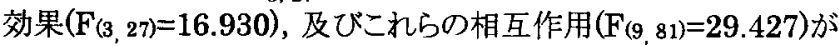
認められた. 交互作用に主効果が認められたため, それぞれの 要因に対して一元配置分散分析を行った. その結果, 図 1 に示し た通りゴムチップタイルとカーペットタイルが組み合わせられた歩 行路においては正答率が有意に低くなることが確認された。 それ
Tab.1 Flooring samples and GB Value.

\begin{tabular}{ccccc}
\hline & porcelain & $\begin{array}{c}\text { rubber-chip } \\
\text { tile }\end{array}$ & carpet & $\begin{array}{c}\text { tactile } \\
\text { indicators }\end{array}$ \\
GB Value & .59 & .33 & .30 & .72 \\
\hline
\end{tabular}

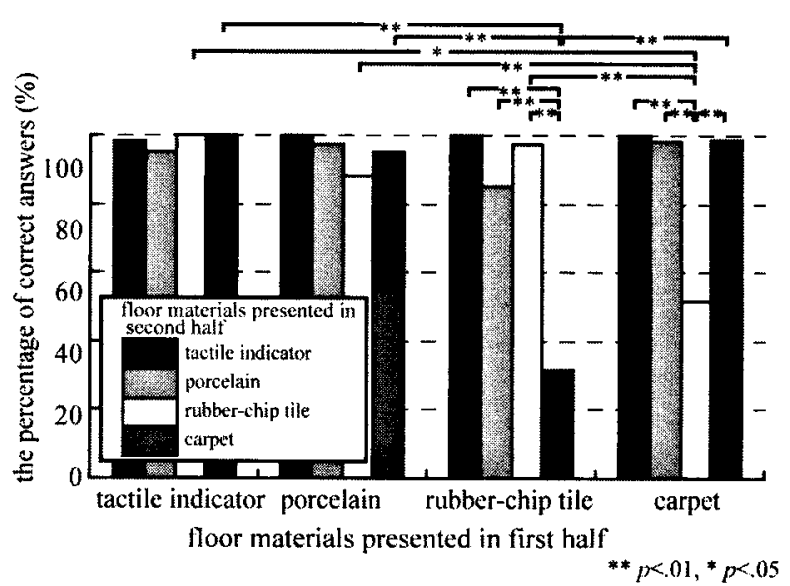

Fig. 1 The percentage of correct answers among the flooring samples.

以外の組み合わせにおいては特に有意差は認められなかった。

\section{4. 考察}

本実験の結果, 正答率と前半部と後半部の GB 係数の差との 相関係数 $\mathbf{r}$ は.88 であり, 床面の硬さの差が大きいほど正答率が 高くなる傾向が認められた. 実際 GB 係数の差が.03 しかないゴ ムチップタイルとカーペットタイルの組み合わせでは, ほとんど識 別できていないことが確認された.一方，磁器タイルとカーペット タイルの組み合わせの場合，ほぼ 100\%素材を識別できることが 確認され，通常使用される誘導ブロックが含まれた組み合わせと の間にも有意差が認められなかった. また, 各床材の摩擦係数を 測定し, 正答率との相関倸数を算出したところ $\mathrm{r}=0.37$ となり, 床 材の滑りやすさは識別時の手がかりとなっていないことが確認さ れた.

更に視覚障害者3名を対象として追実験を行ったところ，本実 験之同様の傾向が確認され, 本研究の有用性が確認された.

以上のから GB 係数で表すことのできる, 床材の硬さの差があ る程度 (本研究では.3 以上) 確保されれば, 現在用いられている 誘導ブロックと同等の識別性を確保できることが確認された。

\section{5. 結論}

本研究では, 様々な硬さの床材を提示し, 歩行中にどの程度 正確にそれらの違いを識別できるかを検証することで, 視覚障害 者に空間を提示するのに妥当な床材の硬さの差を明らかにする ことを目的とした. その結果下記のことが明らかになった.

1) $2 つ の$ 床材間で GB 係数の差が.3以上あれば, 通常の誘導 ブロックと同等に識別できることが確認された.

2) 本研究の結果は視覚障害者を対象としても同様であった.

以上のことから，屋内など安全な箇所においては硬さの異なる 床材を用いることで視覚障害者に空間を提示できる可能性が示 唆された. 